Review

\title{
New Trends in Cancer Therapy: Targeting Ion Channels and Transporters
}

\author{
Annarosa Arcangeli ${ }^{1,2, *}$ and Andrea Becchetti ${ }^{1,2}$ \\ 1 Department of Experimental Pathology and Oncology, University of Florence, Italy \\ 2 Department of Biotechnology and Biosciences, University of Milano-Bicocca, Italy \\ * Author to whom correspondence should be addressed; E-Mail: annarosa.arcangeli@unifi.it; \\ Tel.: +39-055-4598206; Fax: +39-055-4598900.
}

Received: 16 February 2010; in revised form: 25 March 2010 / Accepted: 29 March 2010 / Published: 20 April 2010

\begin{abstract}
The expression and activity of different channel types mark and regulate specific stages of cancer establishment and progression. Blocking channel activity impairs the growth of some tumors, both in vitro and in vivo, which opens a new field for pharmaceutical research. However, ion channel blockers may produce serious side effects, such as cardiac arrhythmias. For instance, $\mathrm{K}_{\mathrm{v}} 11.1$ (hERG1) channels are aberrantly expressed in several human cancers, in which they control different aspects of the neoplastic cell behaviour. hERG1 blockers tend to inhibit cancer growth. However they also retard the cardiac repolarization, thus lengthening the electrocardiographic QT interval, which can lead to life-threatening ventricular arrhythmias. Several possibilities exist to produce less harmful compounds, such as developing specific drugs that bind hERG1 channels in the open state or disassemble the ion channel/integrin complex which appears to be crucial in certain stages of neoplastic progression. The potential approaches to improve the efficacy and safety of ion channel targeting in oncology include: (1) targeting specific conformational channel states; (2) finding ever more specific inhibitors, including peptide toxins, for channel subtypes mainly expressed in well-identified tumors; (3) using specific ligands to convey traceable or cytotoxic compounds; (4) developing channel blocking antibodies; (5) designing new molecular tools to decrease channel expression in selected cancer types. Similar concepts apply to ion transporters such as the $\mathrm{Na}^{+} / \mathrm{K}^{+}$pump and the $\mathrm{Na}^{+} / \mathrm{H}^{+}$exchanger. Pharmacological targeting of these transporters is also currently being considered in anti-neoplastic therapy.
\end{abstract}


Keywords: oncology; hERG; $\mathrm{K}_{\mathrm{v}} 11 ; \mathrm{K}_{\mathrm{v}} 10$; glioma; leukemia; $\mathrm{Na}^{+} / \mathrm{K}^{+}$ATPase; side effects

\section{Introduction}

Evidence tracing back to the seventies indicates that ion channel blockers, especially for $\mathrm{K}^{+}$and $\mathrm{Cl}^{-}$channels, impair neoplastic cell proliferation. These observations were subsequently extended, thus opening a wide field of research on the functional implications of ion channels in the biology of cancer cells [1-2]. Prominent alterations in the expression and activity of ion channels and transporters occur in neoplastic cells. These changes, besides contributing to the promotion of tumorigenesis overall, may mark and stimulate specific progression stages [3]. In agreement with the many observations carried out in vitro, recent studies indicate that blocking the activity of certain voltage-gated channels impairs the growth of some tumours in vivo [4-7]. Encouraging results have also been obtained with inhibitors of the $\mathrm{Na}^{+} / \mathrm{K}^{+}$pump in glioblastoma cells grafted in mice [8]. Analogous approaches are currently under test in rodent models that may have relevance for cancerogenesis, such as chronic inflammatory autoimmune diseases [9].

These studies open new vistas for pharmaceutical research. In principle, targeting ion channels presents considerable advantages for cancer treatment, such as the possibility of convenient (and potentially less toxic) extracellular access. However, ion channels normally exert disparate physiological roles in excitable as well as non-excitable cells. Therefore, channel targeting may produce serious side effects. A clear example, fully discussed below, is provided by $\mathrm{K}_{\mathrm{v}} 11.1$ (hERG1) channels. These normally contribute to the repolarization phase of the cardiac action potential and blocking them may lead to fatal arrhythmias, usually caused by lengthening of the QT interval. However, $\mathrm{K}_{\mathrm{v}} 11.1$ is also frequently expressed in cancer cells [10] and treatment with hERG1 blockers in vivo appears to have therapeutic effects for leukemias [6-7]. It is thus clear that proper calibration of therapy or, even better, production of compounds that preferentially target the channels expressed by tumour cells are experimental tasks that merit further study.

Recently, we have extensively reviewed the manifold aspects of ion channel expression and function in different tumours [3]. In the following paragraph, we provide a brief update of the field. A rough synopsis of ion channels and transporters involved in oncology is shown in Table 1. Next, we focus on the main pharmacological issues, by devoting special attention to the possible strategies for targeting ion channels in cancer and circumventing the side effects.

\section{Channel Expression in Tumour Cells: An Update}

$\mathrm{K}^{+}$channels have attracted most of the work in the field since the early discovery that they often control the proliferation of non-excitable cells. These observations were accompanied by many studies on the expression and function of $\mathrm{K}^{+}$channels in different tumours, and particularly hematologic malignancies. Further investigations have aimed at understanding the contribution of specific channel types to the neoplastic progression. The control of cancer cell proliferation in different experimental models is often modulated by voltage gated $\mathrm{K}^{+}$channels (VGKCs; in particular $\mathrm{K}_{\mathrm{V}} 1.3, \mathrm{~K}_{\mathrm{v}} 10.1$ and $\mathrm{K}_{\mathrm{v}} 11.1$ ), $\mathrm{Ca}^{2+}$-dependent $\mathrm{K}^{+}\left(\mathrm{K}_{\mathrm{Ca}}\right)$ channels (especially $\mathrm{K}_{\mathrm{Ca}} 1.1$ and $\mathrm{K}_{\mathrm{Ca}} 3.1$ ) and two-pore $\left(\mathrm{K}_{2 \mathrm{p}}\right)$ channels (in particular $\mathrm{K}_{2 \mathrm{p}} 2.1$ ). At least in the case of VGKCs and $\mathrm{K}_{\mathrm{Ca}}$, such control can occur through 
the modulation of membrane potential $\left(\mathrm{V}_{\mathrm{m}}\right)$, which in turn regulates transmembrane $\mathrm{Ca}^{2+}$ flow. This mechanism has been proven in breast, prostate and colon cancers and in melanoma, and it may have general importance [1-3]. The phenotype of different cell types is characterized by a specific "calcium signature" dependent on the kinetics, the magnitude and the sub-cellular localization of calcium signals. In turn, intracellular $\mathrm{Ca}^{2+}$ levels participate to the control of cell cycle checkpoints, in normal and neoplastic proliferation [11-13]. It has been repeatedly observed that a dysregulation of the calcium signature in cancer can be mainly attributed to Transient Receptor Potential channels (TRP channels), whose role in tumor progression is increasingly recognized [14,15]. In prostate cancer, for example, classic (TRPC), vanilloid (TRPV) and melastatin (TRPM) TRP channels are all involved, through different mechanisms, in the development of androgen independence. This leads to apoptosis resistance and hence treatment failure [16]. Besides the roles in volume control and cell motility that will be described below, TRP channels' expression could also represent a useful prognostic marker, at least in prostate cancer [17]. Finally, TRP channels are involved in vascular permeability and angiogenesis, with clear implications for tumour growth and metastasis formation $[18,19]$.

Another mechanism by which $\mathrm{K}^{+}$channels control tumor progression is the regulation of cell volume, which requires interplay with $\mathrm{Ca}^{2+}$ and $\mathrm{Cl}^{-}$channels. At least three types of swelling-activated channels are implicated in cancer cell physiology: the volume-regulated anion channels (VRAC), the swelling-activated $\mathrm{K}^{+}$channels TASK-2 and $\mathrm{K}_{\mathrm{Ca}} 1.1$, and the volume sensitive TRP $\mathrm{Ca}^{2+}$ channels, such as TRPV4 and TRPM4 [20]. Cell volume control plays a central role in three crucial aspects of cancer cell biology: cell proliferation, apoptosis and migration. Activation of volume-sensitive $\mathrm{K}^{+}$and $\mathrm{Cl}^{-}$channels underlies the volume decrease which is an early and necessary part of the apoptotic response. Moreover, pioneering work carried out in H. Sontheimer's laboratory determined the role of $\mathrm{K}_{\mathrm{Ca}} 1.1$ (hsloBK) channels, which operate in a finely coordinated manner with $\mathrm{Cl}^{-}$channels to regulate glioma cell invasiveness and metastasis [21]. In particular, ClC-3 is crucially involved in the invasive process [22]. This channel type is inhibited indirectly, but specifically, by a scorpion toxin, chlorotoxin (Cltx), which suggested a pharmacological approach that exploits a radiolabelled Cltx compound (I131-Cltx; [23]), as is illustrated in more detail later. The important contribution of $\mathrm{K}_{\mathrm{Ca}} 3.1$ channels to the regulation of cell migration has also been pointed out. To accomplish this function, $\mathrm{K}_{\mathrm{Ca}} 3.1$ operates in concert with other channels and transporters. The current model envisions ion transport proteins as supporting migration by inducing localized cell volume changes, swelling at the front and shrinkage at the rear. Volume changes at the rear end were proposed to be mediated by $\mathrm{K}_{\mathrm{Ca}} 3.1$ and volumeregulated anion channels (VRAC) [24,25]. In addition, transport proteins like the $\mathrm{Na}^{+} / \mathrm{H}^{+}$exchanger NHE1 generate a characteristic $\mathrm{pH}$ nanomilieu at the cell surface that promotes the formation and release of cell-matrix contacts at the front and rear part of the cell, respectively [26,27]. Ion transporters like NHE1 are also required for persistent directional migration. Finally, TRPC1 channels play an important role in directed cell migration by regulating $\mathrm{Ca}^{2+}$ signaling events within the lamellipodium (reviewed in [24]).

$\mathrm{K}_{\mathrm{v}} 11.1$ also is implicated in motility and cancer invasion [28-30], besides the contribution it gives to regulate proliferation in leukemia [31,32], neuroblastoma [32] and melanoma cells [30]. The mechanism, however, appears to be different from that operated by $\mathrm{K}_{\mathrm{Ca}} 3.1 . \mathrm{K}_{\mathrm{v}} 11.1$ coassembles with the $\beta_{1}$ subunit of integrin receptors, thus forming a macromolecular complex that modulates 
downstream signalling pathways, such as tyrosine kinases and GTPases [33]. In this way, $\mathrm{K}_{\mathrm{v}} 11.1$ controls several aspects of cell physiology, such as migration and survival.

VGKCs often affect also the very first steps of tumor development, as is proven by the frequent upregulation of VGKC transcripts following treatment with chemical carcinogens [34]. Hence, the expression of VGKCs and other structurally related $\mathrm{K}^{+}$channels can be exploited for prognostic purposes in human cancers. For instance, Ousingsawat et al. [34] reported that VGKCs are associated with a poor prognosis in colorectal cancer, whereas $\mathrm{K}_{\mathrm{IR}} 4.1, \mathrm{~K}_{\mathrm{IR}} 3.1$ and $\mathrm{K}_{2 \mathrm{p}} 2.1$ correlate with tumor grade in gliomas, breast and prostate cancers, respectively [3].

The expression of voltage-gated sodium channels (VGSCs) has also been observed to increase in many cancer types, including breast, prostate, lung (both small-cell, SCLC, and non-small-cell, NSCLC), cervical cancer, leukaemia (reviewed in [3]) and mesothelioma cells [35]. Neoplastic cells mainly express the embryonic forms of VGSC $\left(\mathrm{Na}_{\mathrm{v}} 1.5\right.$ in breast and $\mathrm{Na}_{\mathrm{v}} 1.7$ in prostate). In general, VGSCs stimulate some of the cell processes necessary for the metastatic cascade to proceed, although the precise mechanisms are still unclear [36]. In breast, prostate, and NSCLC tumor cells, VGSC activity increases invasiveness by stimulating cysteine cathepsin activity [37]. Non-conductive roles of VGSCs, with possible oncological relevance, such as direct involvement in cell adhesion, are also emerging [38]. As is the case of $\mathrm{K}^{+}$channels, determining VGSC expression (particularly of $\mathrm{Na}_{\mathrm{v}} 1.7$ ) is also useful for prognostic purposes, particularly in prostate cancer [39].

Recent evidence shows that ligand-gated channels are also implicated in neoplastic progression. In particular, the nicotinic acetylcholine receptors (nAChRs) are ionotropic receptors typically activated by acetylcholine and nicotine at concentrations between $100 \mathrm{nM}$ and $1 \mathrm{mM}$. NAChRs regulate cell proliferation, apoptosis and angiogenesis in several tumours, including lung cancers [40-44]. This is suggestive because smoke is an established risk factor for cancer, and particularly lung cancer. Activation of nAChRs stimulates (directly and indirectly) $\mathrm{Ca}^{2+}$ influx, which triggers the release of growth factors and other transmitter molecules. These produce autocrine and paracrine effects that promote proliferation, inhibit apoptosis and stimulate angiogenesis. Moreover, nicotine confers resistance to the chemotherapeutic-induced apoptosis. These effects occur in both SCLC and NSCLC cells, although the intracellular signalling cascades and the nAChR types involved are different. Hence, the molecular network centered on nAChRs is currently considered a promising target for the tobacco-related cancer therapy [45]. Interestingly, from the present perspective, radioligand competition data suggest that several carcinogens produced by tobacco inhalation, namely 4-(methylnitrosamino)-1-(3-pyridyl)-1-butanone (NNK), $\quad N$-nitrosonornicotine $\quad(\mathrm{NNN})$ and diethylnitrosamine (DEN), bind with high affinity to nAChRs [46]. It has thus been proposed that some of the oncogenic effects of these compounds depend on specific activation of nAChRs, which may supplement the well-known effects caused by DNA targeting of several nitrosamine metabolites. Most data concern NSCLC cells, in which nAChRs not only exhibit an altered expression [42], but have been shown to stimulate cell proliferation through up-regulation of signalling pathways downstream to integrins [47].

Finally aquaporins (AQPs) have been recently studied in relation to cancer. AQPs are water channel proteins that facilitate transmembrane water flux. Ectopic AQP expression seems associated with several human cancers [48-50]. Molecular and biochemical studies have begun to clarify the role of AQPs in carcinogenesis. For example, AQP1 is implicated in both angiogenesis and cell cycle control 
[51-53], whereas AQP5 induces many phenotypic changes characteristic of cell transformation in fibroblasts in which it is ectopically expressed [54,55]. The effects of AQPs appear to be mediated by the signalling pathways that include Ras, which is induced by phosphorylation of the PKA consensus site of AQP5. In colon cancer cells, for instance, AQP5 regulates Ras, ERK and RB [55]. Therefore, the general intracellular mechanisms seem similar to those frequently associated to the function of ion channels. Finally, AQP5 promotes epithelial-mesenchymal transition in bronchial epithelial cells, and, consistently, shows a significant association with disease progression in NSCLC [50].

Ion pumps constitute other active players in the neoplastic cell physiology, potentially useful for therapeutic targeting. Thorough work has been carried out by R. Kiss's group on the $\mathrm{Na}^{+} / \mathrm{K}^{+}$ATPase, which turns out to be a potentially useful target for oncologic therapy. The pump's $\alpha 1$ subunit is overexpressed in some cancers [56], such as NSCLC [57] and glioblastomas [58,59]. In the latter, the $\mathrm{Na}^{+}$pump is directly involved in the control of cell migration, thus cooperating with $\mathrm{Cl}^{-}$channels and aquaporins [60]. What is relevant, from the clinical point of view, is that inhibiting migration of highly migrating/invading glioma cells significantly increases their sensitivity to pro-apoptotic drugs. In other words, a potential way to overcome apoptosis resistance is decreasing glioma cell invasiveness [59-61]. Current therapeutic approaches based on these notions are discussed later.

\section{Ion transporters and the control of $\mathrm{pH}$}

Since Warburg's classic work [62], potent control of intra- and extracellular $\mathrm{pH}$ has been known to be a major feature of cancer cells, so much so that it can be considered as one of the cancer hallmarks [63]. Since the late eighties, work from Serrano and co-workers in fibroblasts showed that proton pumps confer increased proliferation rate and resistance to acidic environment. Maintenance of a relatively alkaline cytosol, through active proton extrusion, is thought to produce a permissive state for proliferation [64]. In general, cytoplasmic $\mathrm{pH}\left(\mathrm{pH}_{\mathrm{i}}\right)$ is a most potent modulator of cell function. Displacements of $\mathrm{pH}_{\mathrm{i}}$ from resting levels (7.0-7.5) can arrest cell growth and induce apoptosis [6365]. It has been proposed that tumor cells may have a dual benefit from increased proton extrusion. First, $\mathrm{pH}_{\mathrm{i}}$ is maintained within proliferation-permissive values irrespective of intense glycolysis. Second, extracellular acidification facilitates the activity of the matrix proteases that promote cell migration and invasiveness [63]. Recent work from S. Reshkin's research group contributed to highlight the fundamental role played by the tumor extracellular metabolic microenvironment during malignant invasion. Extracellular environment is mainly acidified by the $\mathrm{Na}^{+} / \mathrm{H}^{+}$exchanger NHE1 and the $\mathrm{H}^{+}$/lactate cotransporter that are typically active in cancer cells. What is more, NHE1 also regulates formation of invadopodia - cell structures that mediate tumor cell migration and invasion. The NHE1 located at invadopodia acidifies the local extracellular nanoenvironment in order to drive proteasedependent and -independent proteolysis of the extracellular matrix (ECM) proteins, thus permitting invasion to occur. The invadopodial ECM digestion modulated by extracellular $\mathrm{pH}$ is also stimulated by serum deprivation, by hypoxia and EGF. The latter stimulates invadopodial digestion and particularly the NHE1-dependent acidification of the peri-invadopodial nanospace. These observations provide a starting place to figure out the mechanisms by which the tumor microenvironment and growth factors interact to drive tumor progression [27,63,65-70]. 
Not surprisingly, considering the above evidence, carbonic anhydrase (CA) has also attracted increasing work in cancer biology, particularly the membrane-bound CA forms [65]. Special attention has been devoted to CA-IX, a hypoxia-inducible, tumor-associated extracellular-facing CA implicated in $\mathrm{pH}$ control of colon, bladder and breast cancer [71-73]. It has been proposed that CA-IX activity helps to vent $\mathrm{CO}_{2}$ from respiring cells, by hydrating extracellular $\mathrm{CO}_{2}$ to $\mathrm{HCO}_{3}{ }^{-}$and $\mathrm{H}^{+}$. Such a facilitated $\mathrm{CO}_{2}$ diffusion maintains a steep outward $\mathrm{CO}_{2}$ gradient, with alkaline $\mathrm{pH}_{\mathrm{i}}$ and acidic $\mathrm{pH}_{\mathrm{e}}$. Such an environment may contribute to stimulate tumor growth and invasiveness. Tumors that do not express CA-IX or other extracellular-facing isoforms (e.g. CA-XII) may resort to different transport mechanisms for proton extrusion, such as lactic acid efflux through monocarboxylic acid transporters (e.g. MCT4, a hypoxia-induced gene-product). The expression and hypoxia-inducibility of CA-IX of different cancer cell lines may provide information about their specific $\mathrm{pH}$ regulation strategies.

\section{Possible Approaches for Ion Channel Targeting in Oncology}

In principle, drugs can affect ion channels through several different mechanisms [74,75]. They can produce direct channel inhibition by blocking the pore or by obstructing the agonist binding site. Moreover, they can modify the channel residence in the different conformational states, by interacting with allosteric sites. Channel proteins are also affected by the composition and physical state of the plasma membrane, which can be also modified by several drugs. Finally, it is increasingly recognized that ion channels form complexes with a variety of membrane proteins, which suggests other possible ways for altering channel function. Many channel inhibitors exert their effects on the extracellular side, which usually makes the treatment is easier to calibrate and decreases aspecific metabolic effects.

Choosing an oncologic therapeutic strategy requires considering the balance between two sometimes conflicting issues. A drug must produce potent and specific inhibition of a given channel type, in order to damage the targeted cell type, without causing important toxic effects in other tissues expressing the same or related channels. Several ways to obtain this goal are possible. In the case of voltage-gated channels, different cell types may express different proportions of channels in the different conformational states, because of their different $\mathrm{V}_{\mathrm{m}}$ dynamics. Therefore, tissue specificity can be obtained by using compounds that preferentially bind these states, even when they poorly discriminate between channel subtypes. Such an approach has been considered for treating neuropathic pain by selectively blocking the VGSCs expressed in depolarized cells, a high proportion of which resides in the inactive state [76]. This requires detailed understanding of the mechanism of drug action, which is however relatively easy to obtain with the modern methods of cell physiology, especially patch-clamp. The latter technique is also invaluable for testing the mechanism of action of newly synthesized compounds, whose design [77,78] should be considerably facilitated by the rapid advances in the determination of the three-dimensional structures of ion channels [79-80]. The details of drug action are more easily carried out on ion channels expressed in heterologous systems. The relevant results can be next confirmed in more physiological preparations, such as primary cultures or brain slices. In this way, detailed mechanistic insight as well as evaluation of the drug's effects on cell processes such as action potential firing, muscle contraction and secretion can be obtained, which is necessary to assess the possible side effects. The possibility of combining biophysical and pathophysiological studies in intact cells makes ion channels very appealing for rational drug development and screening. Nonetheless, targeting ion channels is still an under-exploited therapeutic 
strategy. The recent development of high-throughput automated electrophysiological methods should give considerable impulse to the field. In fact, new compounds with channel-modulating activity have been recently used to treat a variety of disorders (e.g. [81]). However, the side effect issue remains a general problem. Below, we discuss a few exemplary cases regarding both ion channels and ATPase transporters.

Table 1. Some ion channels and transporters relevant in oncology.

\begin{tabular}{|c|c|c|}
\hline Channel type & Function & References \\
\hline $\mathbf{K}^{+}$channels: & Cell proliferation & {$[1-3,28-32,34]$} \\
\hline & Cell invasiveness & \\
\hline & Chemoresistance & \\
\hline & Angiogenesis & \\
\hline & Chemical cancerogenesis & \\
\hline \multirow[t]{3}{*}{$\mathrm{K}_{\mathrm{Ca}}$} & Cell proliferation & \\
\hline & Cell volume & \\
\hline & Cell migration & \\
\hline $\mathrm{K}_{\mathrm{IR}}$ & Cell proliferation & \\
\hline $\mathrm{K}_{2 \mathrm{p}}$ & Cell proliferation & \\
\hline $\mathrm{Ca}^{2+}$ channels: & Cell proliferation & {$[3,11-13]$} \\
\hline $\mathrm{Ca}_{\mathrm{V}}$ & Cell proliferation & \\
\hline SOC & Apoptosis & \\
\hline $\mathrm{Na}^{+}$channels: & Cell migration & {$[3,35-39]$} \\
\hline $\mathrm{Na}_{\mathrm{V}}$ & Cell invasiveness & \\
\hline \multirow[t]{4}{*}{ TRP channels } & Cell proliferation & {$[3,14-19]$} \\
\hline & Apoptosis & \\
\hline & Cell volume & \\
\hline & Angiogenesis & \\
\hline \multirow[t]{2}{*}{$\mathrm{Cl}^{-}$channels } & Cell volume & {$[3,20-25]$} \\
\hline & Cell migration & \\
\hline \multirow[t]{4}{*}{ nAChR } & Cell proliferation & {$[40-47]$} \\
\hline & Apoptosis & \\
\hline & Angiogenesis & \\
\hline & Cell invasiveness & \\
\hline \multirow[t]{2}{*}{ Aquaporins } & Cell cycle control & {$[48-55]$} \\
\hline & Angiogenesis & \\
\hline \multirow[t]{3}{*}{ Sodium pump } & Cell migration & {$[56-61]$} \\
\hline & Cell invasiveness & \\
\hline & Chemoresistance & \\
\hline \multirow{3}{*}{$\begin{array}{l}\mathrm{Na}^{+} / \mathbf{H}^{+} \text {exchanger } \\
\text { (NHE1) }\end{array}$} & Tumor cell metabolism & {$[26-27,63,66-68]$} \\
\hline & Cell invasiveness & \\
\hline & Chemoresistance & \\
\hline \multirow{3}{*}{$\begin{array}{l}\text { Carbonic Anhydrases } \\
\text { (CA-IX, CA-XII) }\end{array}$} & Tumor cell metabolism & {$[65,71-73]$} \\
\hline & Cell growth & \\
\hline & Cell invasiveness & \\
\hline
\end{tabular}

The listed examples refer, with no pretension of exhaustiveness, to the proteins under active study in the field and mentioned in the main text. Table also includes the membrane-bound carbonic anhydrases, which are also mentioned in the text. In addition, the references include a few recent reviews expanding on themes only cursorily treated here (e.g. [3] and [63]). 


\section{The Case of $K_{v} 11.1$ (hERG1 or KCNH2): Specificity and Side Effects}

$\mathrm{K}_{\mathrm{v}} 11$ (also known as ERG, from Ether-à-go-go Related Gene, hERG in humans) is a family of voltage-gated channels that comprises three main subtypes $\left(\mathrm{K}_{\mathrm{v}} 11.1, \mathrm{~K}_{\mathrm{v}} 11.2\right.$ and $\left.\mathrm{K}_{\mathrm{v}} 11.3\right)$. The broad physiological properties of these subtypes are similar, although the specific expression and role in different tissues is debated. Because of their voltage dependent properties, $\mathrm{K}_{\mathrm{v}} 11$ channels can exert different physiological functions. First, they contribute to shape the action potential repolarization, as is typically the case in heart myocytes. These channels activate/inactivate during the long depolarized plateau. Subsequently, during the repolarization phase, they quickly recover from inactivation, thus transiently opening before they close again (deactivate, more precisely) at negative $\mathrm{V}_{\mathrm{m}}$. Second, the steady state properties of $\mathrm{K}_{\mathrm{v}} 11$ are such that a significant fraction of these channels is open at $\mathrm{V}_{\mathrm{m}}$ ' $\mathrm{s}$ around $-40 \mathrm{mV}$. These channels can thus modulate excitability and contribute to the resting $\mathrm{V}_{\mathrm{m}}$ of non-excitable cells, although the precise kinetic features varies between $\mathrm{K}_{\mathrm{v}} 11$ subtypes [82]. In endocrine cells, these channels control the firing frequency, and thus hormone release, as has been shown in pituitary lactotroph [83], $\beta$-pancreatic [84] and chromaffin cells [85]. In general, $\mathrm{K}_{\mathrm{v}} 11$ is widely expressed in the mammalian central nervous system (CNS, [86,87]) and its role in the regulation of neuronal excitability has been demonstrated in a variety of adult and developing rodent preparations [88-92]. Moreover, recent work has revealed a primate-specific cerebral $\mathrm{K}_{\mathrm{v}} 11.1$ isoform (KCNH2-3.1) that controls neuronal excitability and seems to be implicated in neurological disorders [93].

However, current evidence indicates that the most serious side effects observed when administering hERG inhibitors to patients are not caused by endocrine or neurological alterations, but by cardiac arrhythmias. In humans, hERG channels are thought to be the molecular correlate of the pore-forming subunit of the_cardiac $\mathrm{I}_{\mathrm{Kr}}$ current, which contributes to the action potential repolarization phase, for the biophysical reasons illustrated above [94]. Blocking $\mathrm{K}_{\mathrm{v}} 11.1$ retards the cardiac repolarization, which is reflected in prolongation of the electrocardiographic QT interval. Uncontrolled QT interval lenghtening can result in torsade de points $(\mathrm{TdP})$, a life-threatening ventricular arrhythmia that may lead to ventricular fibrillation [95]. In fact, hERG mutations can cause the long QT syndrome [96]. Many $\mathrm{K}_{\mathrm{v}} 11.1$ blockers, such as E4031, Way 123,398, dofetilide and others belong to the class III antiarrhythmic drugs, which can lead to fatal arrhythmias. During the last eighteen years, reports of QT prolongation (associated with hepatotoxicity) have in fact determined more than $60 \%$ of drug withdrawals [97]. In addition, the cardiac side effecs presented by many hERG1 blockers in humans are often accompanied by an unwieldy blocking mechanism, since they bind the intracellular channel face.

These features of $\mathrm{K}_{\mathrm{v}} 11.1$ inhibitors are unfortunate, because ample evidence indicates that hERG expression/activity is implicated in neoplastic progression. In fact, studies in vitro as well as in vivo suggest that hERG1 blockers are worth considering for oncological therapy. Blocking $\mathrm{K}_{\mathrm{v}} 11.1$ tends to arrest cell proliferation in a variety of cultured neoplastic cells [29;31,32;98-100], blocks the invasiveness of colorectal cancer cells [28] and the VEGF-A secretion from cultured glioma cells [101] and myeloid leukaemia cells [29]. What is more, very recent evidence indicates that similar effects are obtained in vivo, as treatment of immunodeficient mice with E4031 decreases (i) the growth of exogenous human gastric and colon cancer cells and (ii) the bone marrow engraftment and peripheral blood invasion of myeloid or lymphoblastic leukaemia cells [6,7]. In the following 
paragraphs, we discuss possible ways to circumvent the problems that therapeutic use of $\mathrm{K}_{\mathrm{v}} 11.1$ blockers may cause.

\subsection{Not all $K_{v} 11.1$ blockers produce arrhythmias}

Apart from class III anthyarrhythmics, $\mathrm{K}_{\mathrm{v}} 11.1$ is blocked by many other compounds, such as some antihistaminics (e.g., terfenadine), prokinetics (e.g., cisapride), antipsychotics (e.g., sertindole) and antibiotics (e.g., erythromycin). This molecular 'promiscuity' resides in the structural features of the intracellular channel cavity, to which most of these drugs bind [97,102-104]. What is interesting from our perspective is that not all of these compounds produce arrhythmogenicity [105]. Verapamil, for example, produces strong hERG inhibition without prolonging the QT interval in both animals and humans. Probably, the effect caused by hERG block is balanced by a concomitant reduction of action potential duration produced by the blockade produced by verapamil on voltage-dependent $\mathrm{Ca}^{2+}$ channels [106]. Other drugs, such as the antipsychotic sertindole, inhibit $\mathrm{K}_{\mathrm{v}} 11.1$ and prolong QT, without inducing torsadogenic effects [102]. The torsadogenic potential of channel blockers is generally unknown, because of the limited knowledge we have about the precise mechanistic relationship between QT prolongation and arrhythmia. Because sertindole has very high affinity for $\mathrm{K}_{\mathrm{v}} 11.1$ [107], it is possible that the higher torsadogenicity of other hERG blockers depends on their lower specificity, which may cause supplementary effects on other ion channels. Therefore, blocking hERG does not necessarily produce fatal arrhythmias and the structure of sertindole may suggest how to synthesize even more specific compounds. This example shows the necessity of obtaining a complete profile of the effects of the most promising drugs on different ion channels. This problem often arises when targeting ion channels. For example, antiepileptic drugs usually exert their action by modulating ion channels. Nevertheless, the mechanism of action is often poorly understood, because the full spectrum of molecular targets of these compounds is generally unknown [108]. To plan rational pharmacological strategies, mechanistic studies should be followed by further tests of the physiological effects on tumor as well as other cell types.

\subsection{Compounds that bind different conformational states or different channel regions}

The ion channel function is characterized by continuous transitions between a few relatively stable conformational states, such as open (active), closed (deactivated) and inactivated (or desensitized, in ligand-gated channels). Therefore, when different cell types have distinct $\mathrm{V}_{\mathrm{m}}$ dynamics, the same channel isoform may present a very different distribution of conformational states. Because many drugs bind conformational states with different efficacy, they may selectively target certain cell types simply because they tend to bind different channel states. This strategy is currently considered in treatment of neuropathic pain [76]. Compounds such as lamotrigine and lidocaine preferentially target open and inactivated voltage-gated $\mathrm{Na}^{+}$channels, without distinguishing the different subunits. The damaged neurons responsible for neuropathic pain are abnormally depolarized, so that the time spent by $\mathrm{Na}^{+}$channels in the open or inactive state is much longer than it normally is in excitable cells. Therefore, cumulative channel inhibition is considerably more effective in damaged neurons.

Similar methods could be applied to cancer therapy. Neoplastic cells are often rather depolarized and their changes in $\mathrm{V}_{\mathrm{m}}$ are usually slow, even when these changes oscillate in phase with the cell cycle stages. Therefore, the proportion of time spent by a voltage-gated channel in a given state can be 
very different in tumors and excitable cells. A recent example that points to the feasibility of this approach is offered $R$-roscovitine [109]. Roscovitine is a cyclin-dependent kinase inhibitor currently tested in phase II clinical trials as an anticancer agent. $R$-roscovitine quickly and reversibly blocks hERG at clinically relevant concentrations. Data suggest that this drugs blocks the open channel, which may explain why it does not produce arrhythmic effects (see Figure 1). HERG is usually open for only a transient phase during the cardiac action potential repolarization, whereas during most of the cardiac lifetime, $\mathrm{K}_{\mathrm{v}} 11.1$ is either deactivated (at negative $\mathrm{V}_{\mathrm{m}}$ ) or inactivated (during the depolarized plateau). Thus, not enough time is available to open channel blockers, at appropriate concentrations, to produce significant hERG block in cardiac cells. On the other hand, a significant fraction of open $\mathrm{K}_{\mathrm{v}} 11.1$ channels should be present in proliferating cells, with typical resting $\mathrm{V}_{\mathrm{m}}$ around $-40 \mathrm{mV}$. Hence, inhibitors that preferentially bind the open channel might produce significant cumulative effects on $\mathrm{K}_{\mathrm{v}} 11.1$-expressing tumor cells, without causing significant side effects on cardiac myocytes. Roscovitine, in particular, also provides the possibility of simultaneous targeting cyclin-dependent kinases and hERG, with potentially cumulative effects. Recent studies have also addressed the frequency-dependence of hERG1 blockade for different compounds, which offers further insight on the possible effects on excitable cells [110]. The notions illustrated above can be extended to the other VGKCs for which drugs addressing specific conformational states are known [111,112].

Figure 1. Differences in the state-dependent block of hERG1 channels by R-roscovitine and class III anthyarrhythmic drugs (E 4031).

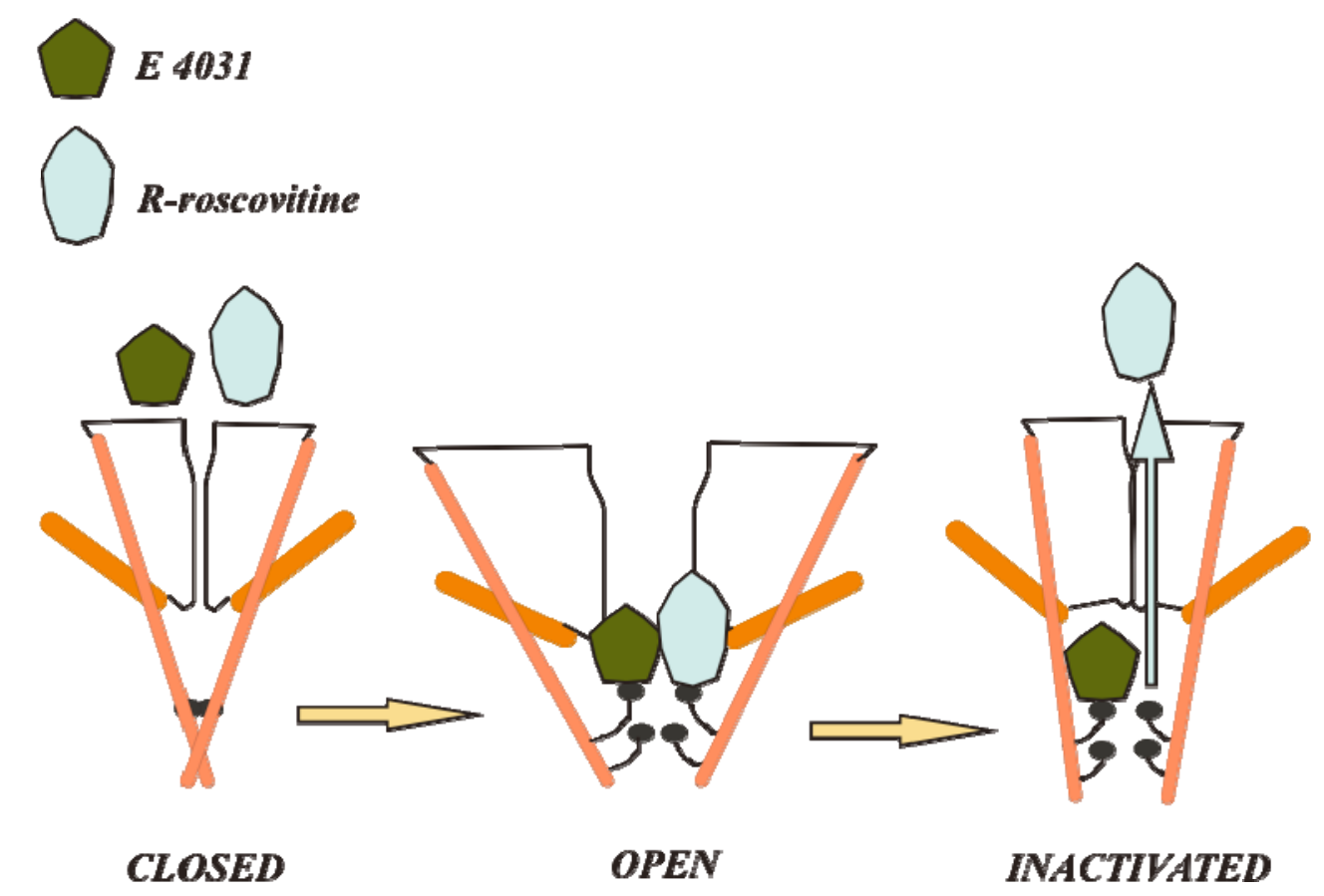

\subsection{Peptide toxins: accessibility from the extracellular side}

A supplementary problem presented by many of the $\mathrm{K}_{\mathrm{v}} 11$-targeting inhibitors is that they often bind to the intracellular side of the channel protein. To develop more convenient drugs a possible starting point is the structure of the several peptide toxins recently found to bind different extracellular channel 
portions, with high specificity. For example, the scorpion toxins BeKm-1 and CnErg1 (ErgTx1) bind the external vestibule when the channel is closed. In this way, they shift the ERG activation curve to the right (more positive). When the channel is open, these peptides also obstruct the channel pore, to different extent, with BeKm-1 probably targeting a deeper pore region [113,114]. Contrary to the above peptides, the sea anemone toxin APETx1 is specific for $\mathrm{K}_{\mathrm{v}} 11.1$ [115]. It alters gating by interacting with the S3b helix, instead of the channel vestibule [116]. Further studies on these peptides could suggest how to develop state-specific drugs fit for therapeutic use. For review about ERG toxins and their mechanisms of action see Wanke and Restano-Cassulini [117]. Supplementary isoformspecific scorpion toxins have been discovered recently [118,119]. For example, five peptides were purified from the venom of Grammostola rosea tarantula. These toxins exhibit different degrees of specificity for tetrodotoxin-sensitive $\mathrm{Na}^{+}$channels and the three main isoforms of $\mathrm{K}_{\mathrm{v}} 11$, but do not block Shaker-related $\mathrm{K}^{+}$channels. Interestingly, these peptides produced both open channel blockade and gating modifications at different concentration ranges. Therefore, it is possible in principle to calibrate a blocker's concentration to obtain the most useful effect.

\section{Recent Oncological Applications of Ion Channel and Transporter Blockade}

We recently reviewed the full spectrum of potential methods to obtain channel inhibition in a way applicable to cancer therapy [3]. In the following paragraphs, we briefly illustrate a few approaches that have already achieved some success (see also Table 2).

\subsection{Specific targeting of ion channels with different methods}

Because in some cases individual channel types can be assigned to specific cancer types [3], it is now possible to seek highly specific blockers to target specific tumor tissues. In effector/memory $\mathrm{T}$ $\left(\mathrm{T}_{\mathrm{EM}}\right)$ cells, $\mathrm{K}_{\mathrm{V}} 1.3$ function is implicated in inflammatory autoimmune diseases such as multiple sclerosis and rheumatoid arthritis [120,121]. Chandy and coworkers recently obtained highly specific targeting of $\mathrm{K}_{\mathrm{v}} 1.3$ with a modified sea anemone toxin (ShK-186). This treatment produces long-term loss of $\mathrm{T}_{\mathrm{EM}}$ cells in mice, with ensuing improvement of autoimmune disease symptoms. Moreover, the toxin spares the $\mathrm{T}$-cell population that confers protection against infection and cancers [122]. However, $\mathrm{T}_{\mathrm{EM}}$ cells exert protective effects only in some cancer types, but not others [123-125]. Therefore, prolonged treatment with $\mathrm{K}_{\mathrm{v}} 1.3$ blockers must be carefully evaluated in each case.

A recent example of the potential usefulness of specific channel-targeting peptide toxins as anticancer compounds is offered by studies in lung cancers. $\alpha$-Cobratoxin specifically inhibits $\alpha 7 \mathrm{nAChRs,}$ those more involved in uncontrolled proliferation. This toxin was found to exert antitumor effects after xenografting either pleural mesothelioma cells [126] or NSCLC cell lines [127] into immunodeficient mice.

In metastatic prostate cancer, promising results have been obtained by using novel blockers for VGNCs with high potency and minimal acute toxicity. These compounds have been used in vitro $[128,129]$ and in human prostate cancer xenografts [130].

Specific ion channel targeting can also be obtained by developing monoclonal blocking antibodies. Although several such tools have been recently produced [131,132], this approach is still in its infancy, as far as cancer therapy is concerned. Use of a monoclonal antibody against $\mathrm{K}_{\mathrm{v}} 10.1$ (EAG-1) channels is described is the next paragraph. 
Finally, specific inhibition can be obtained by using antisense oligonucleotides and small interfering RNAs. Concrete suggestion that this method could be useful in oncology comes from work on the intracellular $\mathrm{Cl}^{-}$channel CLIC4, whose expression increases in keratinocytes after exposure to DNAdamaging compounds. Expressing inducible antisense nucleotides against CLIC4 has been shown to stimulate apoptosis in a squamous cancer cell line. When these cells are transplanted into nude mice, when the CLIC4 level is reduced by expressing an inducible CLIC4 antisense oligonucleotide, cells undergo apoptosis. In tumors derived from transplanting these cells into nude mice, application of the antisense oligonucleotide inhibits tumor growth by increasing apoptosis and reducing proliferation, an effect potentiated by TNF $\alpha$ [133].

Table 2. Possible approaches to target ion channels and transporters in oncology.

\begin{tabular}{|c|c|c|}
\hline Approach & Examples & References \\
\hline $\begin{array}{l}\text { Specific non-peptide } \\
\text { inhibitors }\end{array}$ & $\begin{array}{c}\mathrm{K}_{\mathrm{V}} 11.1 \\
\text { VGNCs } \\
\mathrm{Na}^{+} / \mathrm{K}^{+} \text {ATPase }\end{array}$ & $\begin{array}{c}{[6-7]} \\
{[128-130]} \\
{[134-135]}\end{array}$ \\
\hline $\begin{array}{l}\text { Targeting channel } \\
\text { states }\end{array}$ & $\begin{array}{l}\text { VGNCs } \\
\mathrm{K}_{\mathrm{V}} 11.1\end{array}$ & $\begin{array}{c}{[76]} \\
{[109]}\end{array}$ \\
\hline Use of peptide toxins & $\begin{array}{c}\mathrm{K}_{\mathrm{V}} 11.1 \\
\mathrm{~K}_{\mathrm{V}} 1.3 \\
\mathrm{nAChRs}\end{array}$ & $\begin{array}{c}{[119]} \\
{[122]} \\
{[126,127]}\end{array}$ \\
\hline Blocking antibodies & $\mathrm{K}_{\mathrm{v}} 10.1$ & {$[136]$} \\
\hline $\begin{array}{l}\text { Antisense } \\
\text { oligonucleotides / } \\
\text { siRNAs }\end{array}$ & $\begin{array}{l}\text { CLIC4 } \\
\text { nAChRs }\end{array}$ & $\begin{array}{l}{[133]} \\
{[127]}\end{array}$ \\
\hline $\begin{array}{l}\text { Delivering cytotoxic } \\
\text { compounds }\end{array}$ & $\begin{array}{c}\mathrm{K}_{\mathrm{v}} 10.1 \\
\mathrm{ClC}-3\end{array}$ & $\begin{array}{l}{[136]} \\
{[137]}\end{array}$ \\
\hline
\end{tabular}

Table summarizes the main possible approaches for targeting ion channels and transporters, with possible oncological relevance. The listed examples specifically refer to some channel and transporter types under active study in the field and mentioned in the main text. The references include a few recent reviews expanding on themes only cursorily treated here (e.g. [119]).

\subsection{Using channel-specific toxins and antibodies to deliver cytotoxic compounds}

$\mathrm{K}_{\mathrm{v}} 10.1$ channels are significantly expressed outside the central nervous system only during the progression of particular tumors. No specific inhibitor is known against these channels. Therefore, monoclonal antibodies have been generated, which offer the advantage of being highly specific for 
$\mathrm{K}_{\mathrm{v}} 10.1$ and being unable to cross the blood-brain barrier. Although these antibodies display moderate anti-tumor efficacy, they can be very useful for diagnostic purposes and for local delivery of cytotoxic drugs [136]. A complementary approach is using monoclonal antibodies against tumor-specific membrane proteins to deliver ion channel blockers on a given neoplastic tissue. This method avoids widespread effects of the blocker on other tissues [138-139]. A successful example is targeting of the ClC-3 channels that are implicated in human glioma spread. These channels can be indirectly inhibited by chlorotoxin (Cltx), a scorpion toxin that binds a membrane-bound metalloproteinase. This latter can move within the plasma membrane and thus inhibition of $\mathrm{ClC}-3$ is produced indirectly [137]. A synthetic Cltx derivative labelled with $\mathrm{I}^{131}$ has recently completed phase I clinical trials for patients with high-grade gliomas [23] and a multi-centre phase II trial is currently in progress.

\section{3. $\mathrm{Na}^{+} / \mathrm{K}^{+}$ATPase}

Cardiotonic steroids (cardenolides) are typical natural inhibitors of the $\mathrm{Na}^{+} / \mathrm{K}^{+}$ATPase. Their anticancer effects are usually too weak to allow them to be used clinically at reasonable doses. However, a recently developed hemisynthetic derivative of the cardenolide 2"-oxovoruscharin (UNBS1450) binds to the pump's $\alpha 1$ subunit with 1 to 2 orders of magnitude higher affinity than that displayed by the classical cardenolides. Treatment with UNBS1450 leads to cell death in gliomas overexpressing the $\mathrm{Na}^{+}$pump and, in vivo, prolongs the survival of mice orthotopically grafted with glioblastoma cells $[60,61]$. This compound also produces a marked inhibition of NSCLC cell growth in vitro [57]. Its efficacy in vivo is presently under study in preclinical trials [56]. The probable mechanism of action on glioblastomas is inhibition of cell migration through disorganization of the actin cytoskeleton and stimulation of proautophagic effects. Very recent results indicate that UNBS1450 also exerts antitumor effects on melanoma cells both in vitro and in vivo [134] and seems also very effective on multidrug-resistant cancer cells, generally refractory to chemotherapy [135].

\section{Conclusions}

Ion channels are still somewhat neglected as therapeutic targets, except in typical diseases of excitability processes, such as epilepsy and cardiac arrhythmias. This is somewhat unfortunate because ion channels may offer considerable advantages in terms of mechanistic understanding and clinical potential. A growing body of evidence is determining the specific channel expression and roles in many tumor types $[1-3,140]$. As a consequence, several clinical trials are already in progress for a few channel-targeting compounds. We believe the evidence reviewed here indicates that more widespread efforts should bring interesting pharmacological applications of ion channel (or transporter) inhibitors in oncology.

\section{References}

1. Pardo, L.A. Voltage-gated potassium channels in cell proliferation. Physiology 2004, 19, 285-292.

2. Kunzelmann, K. Ion channels and cancer. J. Memb. Biol. 2005, 205, 159-173.

3. Arcangeli, A.; Crociani, O.; Lastraioli, E.; Masi, A.; Pillozzi, S.; Becchetti, A. Targeting ion channels in cancer: a novel frontier in antineoplastic therapy. Curr. Med. Chem. 2009, 16, 66-93. 
4. Fiske, J.L.; Fomin, V.P.; Brown, M.L.; Duncan, R.L.; Sikes, R.A. Voltage-sensitive ion channels in cancer. Cancer Metastasis Rev. 2006, 25, 439-500.

5. Gómez-Varela, D.; Zwick-Wallasch, E.R.; Knötgen, H.; Sanchez, A.; Hettmann, T.; Ossipov, O.; Weseloh, R.; Contreras-Jurado, C.; Rothe, M.; Stühmer, W.; Pardo, L.A. Monoclonal antibody blockade of the human Eag1 potassium channel function exerts antitumor activity. Cancer Res. 2007, 67, 7343-7349.

6. Pillozzi, S; Accordi, B.; Veltroni, M.; Masselli, M.; Pancrazzi, E.; Galpa, G.; Lippi, A.; Bernini, G.; Basso, G.; Arcangeli, A. Expression and role of hERG1 channels in pediatric acute lymphoblastic leukaemias: shortcoming of drug resistance by hERG1 channel inhibitors in stroma-supported leukaemia cell cultures in vitro. Blood 2007, 110, 222A.

7. Pillozzi, S.; Masselli, M.; De Lorenzo, E.; Cilia, E.; Crociani, O.; Amedei, A.; Accordi, B.; Veltroni, M.; Basso, G.; Campana, D.; Becchetti' A.; Arcangeli, A. Overcoming chemotherapy resistance in childhood acute lymphoblastic leukemia by targeting ion channels. Blood 2009, $114,3085$.

8. Lefranc, F.; Mijatovic, T.; Kondo, Y.; Sauvage, S.; Roland, I.; Debeir, O.; Krstic, D.; Vasic, V.; Gailly, P.; Kondo, S.; Blanco, G.; Kiss, R. Targeting the $\alpha 1$ subunit of the sodium pump to combat glioblastoma cells. Neurosurgery 2008, 62, 211-222.

9. Matheu, M.P.; Beeton, C.; Garcia, A.; Chi, V.; Rangaraju, S.; Safrina, O.; Monaghan, K.; Uemura, M.I.; Li, D.; Pal, S.; de la Maza, L.M.; Monuku, E.; Flügel, A.; Pennington, M.W.; Parker, I.; Chandy, K.G.; Cahalan, M.D. Imaging of effector memory T cells during a delayedtype hypersensitivity reaction and suppression by $\mathrm{K}_{\mathrm{v}} 1.3$ channel block. Immunity 2008, 29, 602-614.

10. Bianchi, L.; Wible, B.; Arcangeli, A.; Taglialatela, M.; Morra, F.; Castaldo, P.; Crociani, O.; Rosati, B.; Faravelli, L.; Olivotto, M.; Wanke, E. Herg encodes a $\mathrm{K}^{+}$current highly conserved in tumors of different histogenesis: a selective advantage for cancer cells? Cancer Res. 1998, 58, 815-822.

11. Munaron, L.; Antoniotti, S.; Fiorio Pla, A.; Lovisolo, D. Blocking $\mathrm{Ca}^{2+}$ entry: a way to control cell proliferation. Curr. Med. Chem. 2004, 11, 1533-1543.

12. Panner, A.; Wurster, R.D. T-type calcium channels and tumor proliferation. Cell Calcium 2006, 40, 253-259.

13. Monteith, G.R.; McAndrew, D.; Faddy, H.M.; Roberts-Thomson, S.J. Calcium and cancer: targeting $\mathrm{Ca}^{2+}$ transport. Nat. Rev. Cancer 2007, 7, 519-530.

14. Bödding, M. TRP proteins and cancer. Cell Signal. 2007, 19, 617-624.

15. Prevarskaya, N.; Zhang, L.; Barritt, G. TRP channels in cancer. Biochem. Biophys. Acta 2007, 1772, 937-946.

16. Bidaux, G.; Flourakis, M.; Thebault, S.; Zholos, A.; Beck, B.; Gkika, D.; Roudbaraki, M.; Bonnal, J.; Mauroy, B.; Shuba, Y.; Skryma, R.; Prevarskaya, N. Prostate cell differentiation status determines transient receptor potential melastatin member 8 channel subcellular localization and function. J. Clin. Invest. 2007, 117, 1647-1657.

17. Zhang, L.; Barritt, G.J. TRPM8 in prostate cancer cells: a potential diagnostic and prognostic marker with a secretory function? Endocr. Relat. Cancer 2006, 13, 27-38. 
18. Bates, D.O.; Hillman, N.J.; Williams, B.; Neal, C.R.; Pocock, T.M. Regulation of microvascular permeability by vascular endothelial growth factors. J. Anat. 2002, 200, 581-597.

19. Hamdollah Zadeh, M.A.; Glass, C.A.; Magnussen, A.; Hancox, J.C.; Bates, D.O. VEGFmediated elevated intracellular calcium and angiogenesis in human microvascular endothelial cells in vitro are inhibited by dominant negative TRPC6. Microcirculation 2008, 15, 605-614.

20. Hoffmann, E.K.; Lambert, I.H.; Pedersen, S.F. Physiology of cell volume regulation in vertebrates. Physiol. Rev. 2009, 89, 193-277.

21. Sontheimer, H. An unexpected role for ion channels in brain tumor metastasis. Exp. Biol. Med. 2008, 233, 779-791.

22. Cuddapah, V.A.; Sontheimer, H. Molecular interaction and functional regulation of ClC-3 by $\mathrm{Ca}^{2+} /$ calmodulin-dependent protein kinase II (CaMKII) in human malignant glioma. J. Biol. Chem. 2010, doi:10.1074/jbc.M109.097675.

23. Mamelak, A.N.; Rosenfeld, S.; Bucholz, R.; Raubitschek, A.; Nabors, L.B.; Fiveash, J.B.; Shen, S.; Khazaeli, M.B.; Colcher, D.; Liu, A.; Osman, M.; Guthrie, B.; Schade-Bijur, S.; Hablitz, D.M.; Alvarez, V.L.; Gonda, M.A. Phase I single-dose study of intracavitary-administered iodine-131-TM-601 in adults with recurrent high-grade glioma. J. Clin. Oncol. 2006, 24, 3644-3650.

24. Schwab, A.; Nechyporuk-Zloy, V.; Fabian, A.; Stock, C. Cells move when ions and water flow. Pflügers Arch. 2007, 453, 421-432.

25. Schwab, A.; Wojnowski, L.; Gabriel, K.; Oberleithner, H. Oscillating activity of a $\mathrm{Ca}^{2+}$-sensitive $\mathrm{K}^{+}$ channel - a prerequisite for migration of alkali-transformed Madin-Darby canine kidney (MDCK-F) cells. J. Clin. Invest. 1994, 93, 1631-36.

26. Stock, C.; Müller, M.; Mally, S.; Noël, J.; Eder, C.; Schwab, A. pH nanoenvironment at the surface of single melanoma cells. Cell Physiol. Biochem. 2007, 20, 679-686.

27. Stock, C.; Schwab, A. Protons make tumor cells move like clockwork. Pflügers Arch. 2009, 458, 981-992.

28. Lastraioli, E.; Guasti, L.; Crociani, O.; Polvani, S.; Hofmann, G.; Witchel, H.; Bencini, L.; Calistri, M.; Messerini, L.; Scatizzi, M.; Moretti, R.; Wanke, E.; Olivotto, M.; Mugnai, G.; Arcangeli, A. Herg1 gene and HERG1 protein are overexpressed in colorectal cancers and regulate cell invasion of tumor cells. Cancer Res. 2004, 64, 606-611.

29. Pillozzi, S.; Brizzi, M.F.; Bernabei, P.A.; Bartolozzi, B.; Caporale, R.; Basile, V.; Boddi, V.; Pegoraro, L.; Becchetti, A.; Arcangeli, A. VEGFR-1 (FLT-1), beta1 integrin, and hERG K ${ }^{+}$ channel for a macromolecular signaling complex in acute myeloid leukemia: role in cell migration and clinical outcome. Blood 2007, 110, 1238-1250.

30. Afrasiabi, E.; Hietamäki, M.; Viitanen, T.; Sukumaran, P.; Bergelin, N.; Törnquist, K. Expression and significance of HERG $(\mathrm{KCNH} 2)$ potassium channels in the regulation of MDAMB-435S melanoma cell proliferation and migration. Cell Signal. 2010, 22, 57-64.

31. Pillozzi, S.; Brizzi, M.F.; Balzi, M.; Crociani, O.; Cherubini, A.; Guasti, L.; Bartolozzi, B.; Becchetti, A.; Wanke, E.; Bernabei, P.A.; Olivotto, M.; Pegoraro, L.; Arcangeli, A. HERG potassium channels are constitutively espressed in primary human acute myeloid leukemia and regulate cell proliferation of normal and leukemic hemopoietic progenitors. Leukemia 2002 , 16, 1791-1798. 
32. Crociani, O.; Guasti, L.; Balzi, M.; Becchetti, A.; Wanke, E.; Olivotto, M.; Wymore, R.S.; Arcangeli, A. Cell cycle-dependent expression of HERG1 and HERG1B isoforms in tumor cells. J. Biol. Chem. 2003, 278, 2947-2955.

33. Arcangeli, A.; Becchetti, A. Complex functional interaction between integrin receptors and ion channels. Trends Cell Biol. 2006, 16, 631-639.

34. Ousingsawat, J.; Spitzner, M.; Puntheeranurak, S.; Terracciano, L.; Tornillo, L.; Bubendorf, L.; Kunzelmann, K.; Schreiber, R. Expression of voltage-gated potassium channels in human and mouse colonic carcinoma. Clin. Cancer Res. 2007, 13, 824-831.

35. Fulgenzi, G.; Graciotti, L.; Faronato, M.; Soldovieri, M.V.; Miceli, F.; Amoroso, S.; Annunziato, L.; Procopio, A.; Taglialatela, M. Human neoplastic mesothelial cells express voltage-gated sodium channels involved in cell motility. Int. J. Biochem. Cell Biol. 2006, 38, 1146-1159.

36. Diss, J.K.; Fraser, S.P.; Djamgoz, M.B. Voltage-gated $\mathrm{Na}^{+}$channels: multiplicity of expression, plasticity, functional implications and pathophysiological aspects. Eur. Biophys. J. 2004, 33, 180-193.

37. Gillet, L.; Roger, S.; Besson, P.; Lecaille, F.; Gore, J.; Bougnoux, P.; Lalmanach, G.; Le Guennec, J.Y. Voltage-gated Sodium Channel Activity Promotes Cysteine Cathepsin-dependent Invasiveness and Colony Growth of Human Cancer Cells. J. Biol. Chem. 2009, 284, 8680-8691.

38. Chioni, A.M.; Brackenbury, W.J.; Calhoun, J.D.; Isom, L.L.; Djamgoz, M.B. A novel adhesion molecule in human breast cancer cells: voltage-gated $\mathrm{Na}^{+}$channel betal subunit. Int. J. Biochem. Cell Biol. 2009, 41, 1216-1227.

39. Diss, J.K.; Stewart, D.; Pani, F.; Foster, C.S.; Walker, M.M.; Patel, A.; Djamgoz, M.B. A potential novel marker for human prostate cancer: voltage-gated sodium channel expression in vivo. Prostate Cancer Prostatic Dis. 2005, 8, 266-273.

40. Maneckjee, R.; Minna, J.D. Opioid and nicotine receptors affect growth regulation of human lung cancer cell lines. Proc. Natl. Acad. Sci. USA 1990, 87, 3294-3298.

41. Dasgupta, P.; Rastogi, S.; Pillai, S.; Ordonez-Ercan, D.; Morris, M.; Haura, E.; Chellappan, S. Nicotine induces cell proliferation by $\beta$-arrestin-mediated activation of Src and Rb-Rafl pathways. J. Clin. Invest. 2006, 111, 31-33.

42. Lam, D.C.; Girard, L.; Ramirez, R.; Chau, W.; Suen, W.; Sheridan, S.; Tin, V.P.C.; Chung, L.; Wong, M.P.; Shay, J.W.; Gazdar, A.F.; Lam, W.; Minna, J.D. Expression of nicotinic acetylcholine receptor subunit genes in non-small-cell lung cancer reveals differences between smokers and nonsmokers. Cancer Res. 2007, 67, 4638-4647.

43. Egleton, R.D.; Brown, K.C.; Dasgupta, P. Nicotinic acetylcholine receptors in cancer: multiple roles in proliferation and inhibition of apoptosis. Trends Pharmacol. Sci. 2008, 29, 151-158.

44. Schuller, H.M. Is cancer triggered by altered signalling of nicotinic acetylcholine receptors? Nat. Rev. Cancer 2009, 9, 195-205.

45. Grozio, A.; Paleari, L.; Catassi, A.; Servent, D.; Cilli, M.; Piccardi, F.; Paganuzzi, M.; Cesario, A.; Granone, P.; Mourier, G.; Russo, P. Natural agents targeting the alpha7-nicotinic-receptor in NSCLC: A promising prospective in anti-cancer drug development. Int. J. Cancer 2008, 122, 1911-1915.

46. Schuller, H.M. Nitrosamines as nicotinic receptor ligands. Life Sci. 2007, 80, 2274-2280. 
47. Zheng, Y.; Ritzenthaler, J.D.; Roman, J.; Han, S. Nicotine stimulates human lung cancer cell growth by inducing fibronectin expression. Am. J. Respir. Cell Mol. Biol. 2007, 37, 681-690.

48. Chae, Y.K.; Kang, S.K.; Kim, M.S.; Woo, J.; Lee, J.; Chang, S.; Kim, D.W.; Kim, M.; Park, S.; Kim, I.; Keam, B.; Rhee, J.; Koo, N.H.; Park, G.; Kim, S.H.; Jang, S.E.; Kweon, I.Y.; Sidransky, D.; Moon, C. Human AQP5 plays a role in the progression of chronic myelogenous leukemia (CML). PLoS One 2008, 3, 2594.

49. Kang, S.K.; Chae, Y.K.; Woo, J.; Kim, M.S.; Park, J.C.; Lee, J.; Soria, J.C.; Jang, S.J.; Sidransky, D.; Moon, C. Role of human aquaporin 5 in colorectal carcinogenesis. Am. J. Pathol. 2008, 173, 518-525.

50. Chae, Y.K.; Woo, J.; Kim, M.J.; Kang, S.K.; Kim, M.S.; Lee, J.; Lee, S.K.; Gong, G.; Kim, Y.H.; Soria, J.C.; Jang, S.J.; Sidransky, D.; Moon, C. Expression of aquaporin 5 (AQP5) promotes tumor invasion in human non small cell lung cancer. PLoS One 2008, 3, e2162.

51. Vacca, A.; Frigeri, A.; Ribatti, D.; Nicchia, G.P.; Nico, B.; Ria, R.; Svelto, M.; Dammacco, F. Microvessel overexpression of aquaporin 1 parallels bone marrow angiogenesis in patients with active multiple myeloma. Br. J. Haematol. 2001, 113, 415-421

52. Saadoun, S.; Papadopoulos, M.C.; Davies, D.C.; Bell, B.A.; Krishna, S. Increased aquaporin 1 water channel expression in human brain tumours. Br. J. Cancer 2002, 87, 621-623.

53. Moon, C.; Soria, J.C.; Jang, S.J.; Lee, J.; Hoque, M.O.; Sibony, M.; Trink, B.; Chang, Y.S.; Sidransky, D.; Mao, L. Involvement of aquaporins in colorectal carcinogenesis. Oncogene 2003, 22, 6699-6703.

54. Woo, J.; Lee, J.; Chae, Y.K.; Kim, M.S.; Baek, J.H.; Park, J.C.; Park, M.J.; Smith, I.M.; Trink, B.; Ratovitski, E.; Lee, T.; Park, B.; Jang, S.J.; Soria, J.C.; Califano, J.A.; Sidransky, D.; Moon, C. Overexpression of AQP5, a putative oncogene, promotes cell growth and transformation. Cancer Lett. 2008, 264, 54-62.

55. Woo, J.; Lee, J.; Kim, M.S.; Jang, S.J.; Sidransky, D.; Moon, C. The effect of aquaporin 5 overexpression on the Ras signaling pathway. Biochem. Biophys. Res. Commun. 2008, 367, 291-298.

56. Mijatovic, T.; Van Quaquebeke, E.; Delest, B.; Debeir, O.; Darro, F.; Kiss, R. Cardiotonic steroids on the road to anti-cancer therapy. Biochim. Biophys. Acta 2007, 1776, 32-57.

57. Mijatovic, T; Roland, I.; Van Quaquebeke, E.; Nilsson, B.; Mathieu, A.; van Vynckt, F.; Darro, F.; Blanco, G.; Facchini, V.; Kiss, R. The alpha1 subunit of the sodium pump could represent a novel target to combat non-small cell lung cancers. J. Pathol. 2007, 212, 170-179.

58. Senner, V.; Schmidtpeter, S.; Braune, S.; Puttmann, S.; Thanos, S.; Bartsch, U.; Schachner, M.; Paulus, W. AMOG/beta2 and glioma invasion: Does loss of AMOG make tumour cells run amok? Neuropathol. Appl. Neurobiol. 2003, 29, 370-377.

59. Lefranc, F.; Brotchi, J.; Kiss, R. Present and future issues in the treatment of malignant gliomas, with a special emphasis on cell migration and the resistance of migrating glioma cells to apoptosis. J. Clin. Oncol. 2005, 23, 2411-2422.

60. Lefranc, F.; Kiss, R. The sodium pump $\alpha 1$ subunit as a potential target to combat apoptosisresistant glioblastomas. Neoplasia 2008, 10, 198-206. 
61. Lefranc, F.; Rynkowski, M.; Dewitte, O.; Kiss, R. Present and potential future adjuvant issues in high-grade astrocytic glioma treatment. In Advances and Technical Standards in Neurosurgery; Pickard, J.D., Ed.; Springer-Verlag: Wien, Austria, 2009.

62. Warburg, O. On the origins of cancer cells. Science 1956, 123, 309-314.

63. Cardone, R.A.; Casavola, V.; Reshkin, S.J. The role of disturbed $\mathrm{pH}$ dynamics and the $\mathrm{Na}^{+} / \mathrm{H}^{+}$ exchanger in metastasis. Nat. Rev. Cancer 2005, 5, 786-795.

64. Perona, R.; Serrano, R. Increased $\mathrm{pH}$ and tumorigenicity of fibroblasts expressing a yeast proton pump. Nature 1988, 334, 438-440.

65. Swietach, P.; Vaughan-Jones, R.D.; Harris, A.L. Regulation of tumor $\mathrm{pH}$ and the role of carbonic anhydrase 9. Cancer Metastasis Rev. 2007, 26, 299-310.

66. Cardone, R.A.; Bellizzi, A.; Busco, G.; Weinmann, E.J.; Dell'Aquila, M.E.; Casavola, V.; Azzariti, A.; Mangia, A.; Paradiso, A.; Reshkin, S.J. The NHERF1 PDZ2 domain regulates PKA-RhoA-p38 mediated NHE1 activation and invasion in breast tumor cells. Mol. Biol. Cell 2007, 18, 1768-1780.

67. Cardone, R.A.; Busco, G.; Greco, M.R.; Bellizzi, A.; Accardi, R.; Cafarelli, A.; Monterisi, S.; Carratù, P.; Casavola, V.; Paradiso, A.; Tommasino, M.; Reshkin, S.J. HPV16 E7-dependent transformation activates NHE1 through a PKA-RhoA-induced inhibition of p38alpha. PLoS One 2008, 3, e3529.

68. Mangia, A.; Chiriatti, A.; Bellizzi, A.; Malfettone, A.; Stea, B.; Zito, F.A.; Reshkin, S.J.; Simone, G.; Paradiso, A. Biological role of NHERF1 protein expression in breast cancer. Histopathology 2009, 55, 600-608.

69. Harguindey, S.; Arranz, J.L.; Wahl, M.L.; Orive, G.; Reshkin, S.J. Proton transport inhibitors as potentially selective anticancer drugs. Anticancer Res. 2009, 29, 2127-2136.

70. Favia, A.; Guerra, L.; Fanelli, T.; Cardone, R.A.; Monterisi, S.; Di Sole, F.; Castellani, S.; Chen, M.; Seidler, U.; Reshkin, S.J.; Conese, M.; Casavola, V. $\mathrm{Na}^{+} / \mathrm{H}^{+}$exchanger regulatory factor 1 overexpression-dependent increase of cytoskeleton organization is fundamental in the rescue of F508del cystic fibrosis trans membrane conductance regulator in human air way CFBE41o-cells. Mol. Biol. Cell 2010, 21, 73-86.

71. Kivela, A.J.; Parkkila, S.; Saarnio, J.; Karttunen, T.J.; Kivela, J.; Parkkila, A.K.; Pastorekova, S.; Pastorek, J.; Waheed, A.; Sly, W.S.; Rajaniemi, H. Expression of transmembrane carbonic anhydrase isoenzymes IX and XII in normal human pancreas and pancreatic tumours. Histochem. Cell Biol. 2000, 114, 197-204.

72. Ivanov, S.; Liao, S.Y.; Ivanova, A.; Danilkovitch-Miagkova, A.; Tarasova, N.; Weirich, G.; Merrill, M.J.; Proescholdt, M.A.; Oldfield, E.H.; Lee, J.; Zavada, J.; Waheed, A.; Sly, W.S.; Lerman, M.I.; Stanbridge, E.J. Expression of hypoxia-inducible cell-surface transmembrane carbonic anhydrases in human cancer. Am. J. Pathol. 2001, 158, 905-919.

73. Swietach, P.; Patiar, S.; Supuran, C.T.; Harris, A.L.; Vaughan-Jones, R.D. The role of carbonic anhydrase 9 in regulating extracellular and intracellular $\mathrm{pH}$ in three-dimensional tumor cell growth. J. Biol. Chem. 2009, 284, 20299-20310.

74. Andersen, O.S. Perspectives on how to drug an ion channel. J. Gen. Physiol. 2008, $131,395-397$. 
75. Becchetti, A.; Arcangeli A. A comment on ion channels as pharmacological targets in oncology. J. Gen. Physiol. 2008, 132, 313-314.

76. Kaczorowski, G.J.; McManus, O.B.; Priest, B.T.; Garcia, M.L. Ion channels as drug targets: the next GPCRs. J. Gen. Physiol. 2008, 131, 399-405.

77. Cavalli, A.; Poluzzi, E.; De Ponti, F.; Recanatini, M. Toward a pharmacophore for drugs inducing the long QT syndrome: insights from a CoMFA study of HERG $\mathrm{K}^{+}$channel blockers. $J$. Med. Chem. 2002, 45, 3844-3853.

78. Recanatini, M.; Cavalli, A.; Masetti, M. Modeling HERG and its interactions with drugs: recent avances in light of current potassium channel simulations. Chem. Med. Chem. 2008, 3, 523-535.

79. Doyle, D.A.; Morais Cabral, J.; Pfuetzner, R.A.; Kuo, A.; Gulbis, J.M.; Cohen, S.L.; Chait, B.T.; MacKinnon, R. The structure of the potassium channel: molecular basis of $\mathrm{K}^{+}$conduction and selectivity. Science 1998, 280, 69-77.

80. Dutzler, R.; Campbell, E.B.; Cadene, M.; Chait, B.T.; MacKinnon, R. X-ray structure of a ClC chloride channel at $3.0 \AA \AA$ reveals the molecular basis of anion selectivity. Nature 2002, 415, 287-294.

81. Xie, M.; Holmqvist, M.H.; Hsia, A.Y. www.currentdrugdiscovery.com, April 2004.

82. Shi, W.; Wymore, R.S.; Wang, H.-S.; Pan, Z.; Cohen, I.S.; McKinnon, D.; Dixon, J.E. Identification of two nervous system-specific members of the erg potassium channel gene family. J. Neurosci. 1997, 17, 9423-9432.

83. Schäfer, R.; Wulfsen, I.; Behrens, S.; Weinsberg, F.; Bauer, C.K.; Schwarz, J.R. The erg-like potassium current in rat lactotrophs. J. Physiol. 1999, 518, 410-416.

84. Rosati, B.; Marchetti, P.; Crociani, O.; Lecchi, M.; Lupi, R.; Arcangeli, A.; Olivotto, M.; Wanke, E. Glucose- and arginine-induced insulin secretion by human pancreatic beta-cells: the role of HERG $\mathrm{K}(+)$ channels in firing and release. FASEB J. 2000, 14, 2601-2610.

85. Gullo, F.; Ales, E.; Rosati, B.; Lecchi, M.; Masi, A.; Guasti, L.; Cano-Abad, M.F.; Arcangeli, A.; Lopez, M.G.; Wanke, E. ERG $\mathrm{K}^{+}$channel blockade enhances firing and epinephrine secretion in rat chromaffin cells: the missing link to LQT2-related sudden death? FASEB J. 2003, 17, 330-332.

86. Papa, M.; Boscia, F.; Canitano, A.; Castaldo, P.; Sellitti, S.; Annunziato, L.; Taglialatela, M. Expression pattern of the ether-à-gogo-related (ERG) $\mathrm{K}^{+}$channel-encoding genes ERG1, ERG2, and ERG3 in the adult rat central nervous system. J. Comp. Neurol. 2003, 466, 119-135.

87. Guasti, L.; Cilia, E.; Crociani, O.; Hofmann, G.; Polvani, S.; Becchetti, A.; Wanke, E.; Tempia, F.; Arcangeli, A. Expression pattern of the Ether-à-go-go-related (ERG) family proteins in the adult mouse central nervous system: evidence for coassembly of different subunits. J. Comp. Neurol. 2005, 491, 157-174.

88. Sacco, T.; Bruno, A.; Wanke, E.; Tempia, F. Functional roles of an ERG current isolated in cerebellar Purkinje neurons. J. Neurophysiol. 2003, 90, 1817-1828.

89. Furlan, F.; Guasti, L.; Avossa, D.; Becchetti, A.; Cilia, E.; Ballerini, L.; Arcangeli, A. Interneurons transiently express the $\mathrm{ERG} \mathrm{K}^{+}$channels during development of mouse spinal networks in vitro. Neuroscience 2005, 135, 1179-1192.

90. Furlan, F.; Taccola, G.; Grandolfo, M.; Guasti, L.; Arcangeli, A.; Nistri, A.; Ballerini, A. ERG conductance expression modulates the excitability of ventral horn GABAergic interneurons that 
control rhythmic oscillations in the developing mouse spinal cord. J. Neurosci. 2007, 27, 919-928.

91. Pessia, M.; Servettini, I.; Panichi, R.; Guasti, L.; Grassi, S.; Arcangeli, A.; Wanke, E.; Pettorossi, V.E. ERG voltage-gated $\mathrm{K}^{+}$channels regulate excitability and discharge dynamics of the medial vestibular nucleus neurons. J. Physiol. 2008, 586, 4877-4890.

92. Hirdes, W.; Napp, N.; Wulfsen, I.; Schweizer, M.; Schwarz, J.R.; Bauer, C.K. Erg K ${ }^{+}$currents modulate excitability in mouse mitral/tufted neurons. Pflügers Arch. 2009, 459, 55-70.

93. Huffaker, S.J.; Chen, J.; Nicodemus, K.K.; Sambataro, F.; Yang, F.; Mattay, V.; Lipska, B.K.; Hyde, T.M.; Song, J.; Rujescu, D.; Giegling, I.; Mayilyan, K.; Proust, M.J.; Soghoyan, A.; Caforio, G.; Callicott, J.H.; Bertolino, A.; Meyer-Lindenberg, A.; Chang, J.; Ji, Y.; Egan, M.F.; Goldberg, T.E.; Kleinman, J.F.; Lu, B.; Weinberger, D.R. A primate-specific, brain isoform of KCNH2 affects cortical physiology, cognition, neuronal repolarization and risk of schizophrenia. Nat. Med. 2009, 15, 509-518.

94. Sanguinetti, M.C.; Jang, C.; Curran, M.E.; Keating, M.T. A mechanistic link between an inherited and an acquired cardiac arrhythmia: HERG encodes the Ikr potassium channel. Cell 1995, 81, 299-307.

95. Witchel, H.J.; Hancox, J.C. Familial and acquired long QT syndrome and the cardiac rapid delayed rectifier potassium current. Clin. Exp. Pharmacol. Physiol. 2000, 27, 753-766.

96. Curran, M.E.; Splawski, I.; Timothy, K.W.; Vincent, G.M.; Green, E.D.; Keating, M.T. A molecular basis for cardiac arrhythmia: HERG mutations cause long QT syndrome. Cell 1995, 80, 795-803.

97. Raschi, E.; Vasina, V.; Poluzzi, E.; De Ponti, F. The hERG $\mathrm{K}^{+}$channel: target and antitarget strategies in drug development. Pharmacol. Res. 2008, 57, 181-195.

98. Smith, G.A.M.; Tsui, H.; Newell, E.W.; Jiang, X.; Zhu, X.; Tsui, F.W.L.; Schlichter, L.C. Functional up-regulation of HERG $\mathrm{K}^{+}$in neoplastic hematopoietic cells. J. Biol. Chem. 2002, 277, 18528-18534.

99. Shao, X.; Wu, K.; Hao, Z.; Hong, L.; Zhang, J.; Fan, D. The potent inhibitory effects of cisapride, a specific blocker for humans ether-à-go-go-related gene (HERG) channel, on gastric cancer. Cancer Biol. Ther. 2005, 4, 295-301.

100. Shao, X.; Wu, K.; Guo, X.; Xie, M.; Zhang, J.; Fan, D. Expression and significance of HERG protein in gastric cancer. Cancer Biol. Ther. 2008, 7, 45-50

101. Masi, A.; Becchetti, A.; Restano-Cassulini, R.; Polvani, S.; Hofmann, G.; Buccoliero, A.M.; Paglierani, M.; Pollo, B.; Taddei, G.L.; Gallina, P.; Di Lorenzo, M.; Franceschetti, S.; Wanke, E.; Arcangeli, A. hERG1 channels are overexpressed in glioblastoma multiforme and modulate VEGF secretion in glioblastoma cell lines. Br. J. Cancer 2005, 93, 781-792.

102. Shah, R.R. Drug-induced QT interval prolongation - regulatory guidance and perspectives on hERG channel studies. Novartis Found Symp. 2005, 266, 251-280.

103. Stanfield, P.J.; Sutcliffe, M.J.; Mitcheson, J.S. Molecular mechanisms for drug interactions with hERG that cause long QT syndrome. Exp. Opin. Drug Metab. Toxicol. 2008, 2, 81-94.

104. Mitcheson, J.S. hERG potassium channels and the structural basis of drug-induced arrhythmias. Chem. Res. Toxicol. 2008, 21, 1005-1010. 
105. Wallis, R.M. Integrated risk assessment and predictive value to humans of non-clinical repolarization assays. Br. J. Pharmacol. 2010, 159, 115-121.

106. Chouabe, C.; Drici, M.D.; Romey, G.; Barhanin, J.; Lazdunski, M. hERG and KvLQT1/IsK, the cardiac $\mathrm{K}^{+}$channels involved in long QT syndromes, are targets for calcium channel blockers. Mol. Pharmacol. 1998, 54, 695-703.

107. Rampe, D.; Murawsky, M.K.; Gran, J.; Lewis, E.W. The antipsychotic agent sertindole is a high affinity antagonist of the human cardiac potassium channel HERG. J. Pharmacol. Exp. Ther. 1998, 286, 788-793.

108. Rogawski, M.A.; Löscher, W. The neurobiology of antiepileptic drugs. Nat. Rev. Neurosci. 2004, 5, 553-564.

109. Ganapathi, S.B.; Kester, M.; Elmslie, K.S. State-dependent block of HERG potassium channels by $R$-roscovitine: implications for cancer therapy. Am. J. Physiol. Cell Physiol. 2009, 296, C701-C710.

110. Stork, D.; Timin, E.N.; Berjukow, S.; Huber, C.; Hohaus, A.; Auer, M.; Hering, S. State dependent dissociation of HERG channel inhibitors. Br. J. Pharmacol. 2007, 151, 1368-1376.

111. Nguyen, A.; Kath, J.C.; Hanson, D.C.; Biggers, M.S.; Canniff, P.C.; Donovan, C.B.; Mather, R.J.; Bruns, M.J.; Rauer, H.; Aiyar, J.; Lepple-Wienhues, A.; Gutman, G.A.; Grissmer, S.; Cahalan, M.D.; Chandy, K.G. Novel nonpeptide agents potently block the C-type inactivated conformation of $\mathrm{K}_{\mathrm{v}} 1.3$ and suppress T cell activation. Mol. Pharmacol. 1996, 50, 1672-1679.

112. Ader, C.; Schneider, R.; Hornig, S.; Velisetty, P.; Wilson, E.M.; Lange, A.; Giller, K.; Ohmert, I.; Martin-Eauclaire, M.F.; Trauner, D.; Becker, S.; Pongs, O.; Baldus, M. A structural link between inactivation and block of a $\mathrm{K}^{+}$channel. Nat. Struct. Mol. Biol. 2008, 15, 605-612.

113. Milnes, J.T.; Dempsey, C.E.; Ridley, J.M.; Crociani, O.; Arcangeli, A.; Hancox, J.C.; Witchel, H.J. Preferential closed channel blockade of HERG potassium currents by chemically synthesised BeKm-1 scorpion toxin. FEBS Lett. 2003, 547, 20-26.

114. Zhang, M.; Korolkova, Y.V.; Liu, J.; Jiang, M.; Grishin, E.V.; Tseng, G.-N. BeKm-1 is a HERGspecific toxin that shares the structure with ChTx but the mechanism of action with ErgTx1. Biophys. J. 2003, 84, 3022-3036.

115. Restano-Cassulini, R.; Korolkova, Y.V.; Diochot, S.; Gurrola, G.; Guasti, L.; Possani, L.D.; Lazdunski, M.; Grishin, E.V.; Arcangeli, A.; Wanke, E. Species diversity and peptide toxins blocking selectivity of ether-à-go-go-related gene subfamily $\mathrm{K}^{+}$channels in the central nervous system. Mol. Pharmacol. 2006, 69, 1673-1683.

116. Zhang, M.; Liu, X.S.; Diochot, S.; Lazdunski, M.; Tseng, G.N. APETx1 from sea anemone Anthopleura elegantissima is a gating modifier peptide toxin of the human ether-à-go-go- related potassium channel. Mol. Pharmacol. 2007, 72, 259-268.

117. Wanke, E.; Restano-Cassulini, R. Toxins interacting with ether-à-go-go-related gene voltagedependent potassium channels. Toxicon 2007, 49, 239-248.

118. Restano-Cassulini, R.; Olamendi-Portugal, T.; Zamudio, F.; Becerril, B.; Possani, L.D. Two novel ergtoxins, blockers of $\mathrm{K}^{+}$channels, purified from the Mexican scorpion Centruroides elegans elegans. Neurochem. Res. 2008, 33, 1525-1533.

119. Redaelli, E.; Restano-Cassulini, R.; Fuentes Silva, D.; Clement, H.; Schiavon, E.; Zamudio, F.Z.; Odell, G.; Arcangeli, A.; Clare, J.J.; Alagon, A.; Rodriguez de la Vega, R.C.; Possani, L.D.; 
Wanke, E. Target promiscuity and heterogeneous effects of Tarantula venom peptides affecting $\mathrm{Na}^{+}$and $\mathrm{K}^{+}$ion channels. J. Biol. Chem. 2010, 285, 4130-4142.

120. Panyi, G.; Possani, L.D.; Rodríguez de la Vega, R.C.; Gáspár, R.; Varga, Z. K ${ }^{+}$channel blockers: novel tools to inhibit T cell activation leading to specific immunosuppression. Curr. Pharm. Des. 2006, 12, 219.

121. Wulff, H.; Pennington, M. Targeting effector memory T-cells with Kv1.3 blockers. Curr. Opin. Drug Discov. Devel. 2007, 10, 438.

122. Beeton, C.; Wulff, H.; Standifer, N.E.; Azam, P.; Mullen, K.M.; Pennington, M.W.; KolskiAndreaco, A.; Wei, E.; Grino, A.; Counts, D.R.; Wang, P.H.; LeeHealey, C.J.; S Andrews, B.; Sankaranarayanan, A.; Homerick, D.; Roeck, W.W.; Tehranzadeh, J.; Stanhope, K.L.; Zimin, P.; Havel, P.J.; Griffey, S.; Knaus, H.; Nepom, G.T.; Gutman, G.A.; Calabresi, P.A.; Chandy, K.G. $\mathrm{K}_{\mathrm{V}} 1.3$ channels are a therapeutic target for $\mathrm{T}$ cell-mediated autoimmune diseases. Proc. Natl. Acad. Sci. USA 2006, 103, 17414-17419.

123. Pagès, F.; Berger, A.; Camus, M.; Sanchez-Cabo, F.; Costes, A.; Molidor, R.; Mlecnik, B.; Kirilovsky, A.; Nilsson, M.; Damotte, D.; Meatchi, T.; Bruneval, P.; Cugnenc, P.H.; Trajanoski, Z.; Fridman, W.H.; Galon, J. Effector memory T cells, early metastasis, and survival in colorectal cancer. N. Engl. J. Med. 2005, 353, 2654-2666.

124. Klebanoff, C.A.; Gattinoni, L.; Torabi-Parizi, P.; Kerstann, K.; Cardones, A.R.; Finkelstein, S.E.; Palmer, D.C.; Antony, P.A.; Hwang, S.T.; Rosenberg, S.A.; Waldmann, T.A., Restifo, N.P. Central memory self/tumor-reactive CD8+ T cells confer superior antitumor immunity compared with effector memory T cells. Proc. Natl. Acad. Sci. USA 2005, 102, 9571-9576.

125. Galon, J.; Costes, A.; Sanchez-Cabo, F.; Kirilovsky, A.; Mlecnik, B.; Lagorce-Pagès, C.; Tosolini, M.; Camus, M.; Berger, A.; Wind, P.; Zinzindohoué, F.; Bruneval, P.; Cugnenc, P.H.; Trajanoski, Z.; Fridman, W.H.; Pagès F. Type, density, and location of immune cells within human colorectal tumors predict clinical outcome. Science 2006, 313,1960-1964.

126. Paleari, L.; Negri, E.; Catassi, A.; Cilli, M.; Servent, D.; D’Angelillo, R.; Cesario, A.; Russo, P.; Fini, M. Inhibition of nonneuronal alpha7-nicotinic receptor for lung cancer treatment. Am. J. Respir. Crit. Care Med. 2009, 179, 1141-1150.

127. Paleari, L.; Sessa, F.; Catassi, A.; Servent, D.; Mourier, G.; Doria-Miglietta, G.; Ognio, E.; Cilli, M.; Dominioni, L.; Paolucci, M.; Calcaterra, A.; Cesario, A.; Margaritora, S.; Granone, P.; Russo, P. Inhibition of non-neuronal alpha7-nicotinic receptor reduces tumorigenicity in A549 NSCLC xenografts. Int. J. Cancer 2009, 125, 199-211.

128. Brown, M.L.; Zha, C.C.; Van Dyke, C.C.; Brown, G.B.; Brouillette, W.J. Comparative molecular field analysis of hydantoin binding to the neuronal voltage-dependent sodium channel. J. Med. Chem. 1999, 42, 1537-1545.

129. Anderson, J.D.; Hansen, T.P.; Lenkowski, P.W.; Walls, A.M.; Choudhury, I.M.; Schenck, H.A.; Friehling, M.; Höll, G.M.; Patel, M.K.; Sikes, R.A.; Brown, M.L. Voltage-gated sodium channel blockers as cytostatic inhibitors of the androgen-independent prostate cancer cell line PC-3. Mol. Cancer Ther. 2003, 2, 1149-1154.

130. Sikes, R.A.; Walls, A.M.; Brennen, W.N.; Anderson, J.D.; Choudhury-Mukherjee, I.; Schenck, H.A.; Brown, M.L. Therapeutic approaches targeting prostate cancer progression using novel voltage-gated ion channel blockers. Clin. Prostate Cancer 2003, 2, 181-187. 
131. Xu, S.Z.; Zeng, F.; Lei, M.; Li, J.; Gao, B.; Xiong, C.; Sivaprasadarao, A.; Beech, D.J. Generation of functional ion channel tools by E3 targeting. Nat. Biotechnol. 2005, 23, 1289-1293.

132. Martial, S.; Giorgelli, J-L.; Renaudo, A.; Derijard, B.; Soriani, O. SP600125 inhibits $\mathrm{K}_{\mathrm{v}}$ channels through a JNK-independent pathway in cancer cells. Biochem. Biophys. Res. Commun. 2008, 366, 944-950.

133. Suh, K.S.; Mutoh, M.; Gerdes, M.; Yuspa, S.H. CLIC4, an intracellular chloride channel protein, is a novel molecular target for cancer therapy. J. Investig. Dermatol. Symp. Proc. 2005, 10, 105-109.

134. Mathieu, V.; Pirker, C.; de Lassalle, E.M.; Vernier, M.; Mijatovic, T.; Deneve, N.; Gaussin, J.F.; Dehoux, M.; Lefranc, F.; Berger, W.; Kiss, R. The sodium pump al subunit: a disease progression-related target for metastatic melanoma treatment. J. Cell. Mol. Med. 2009, 3960-3972.

135. Mijatovic, T.; Jungwirth, U.; Heffeter, P.; Hoda, M.A.; Dornetshuber, R.; Kiss, R.; Berger, W. The $\mathrm{Na}^{+} / \mathrm{K}^{+}$ATPase is the Achilles heel of multi-drug-resistant cancer cells. Cancer Lett. 2009, 282, 30-34.

136. Gómez-Varela, D.; Zwick-Wallasch, E.; Knötgen, H.; Sánchez, A.; Hettmann, T.; Ossipov, D.; Weseloh, R.; Contreras-Jurado, C.; Rothe, M.; Stühmer, W.; Pardo, L.A. Monoclonal antibody blockade of the human Eag1 potassium channel function exerts antitumor activity. Cancer Res. 2007, 67, 7343-7349.

137. Deshane, J.; Garner, C.C.; Sontheimer, H. Chlorotoxin inhibits glioma cell invasion via matrix metalloproteinase-2. J. Biol. Chem. 2003, 278, 4135-4144.

138. Hinman, L.M.; Hannann, P.R.; Wallace, R.; Menendez, A.T.; Durr, M.E.; Upeslacis, J. Preparation and characterization of monoclonal antibody conjugates of the calicheamicins: a novel and potent family of antitumor antibiotics. Cancer Res. 1993, 53, 3336-3342.

139. Singh, Y.; Palombo, M.; Sinko, P.J. Recent trends in targeted anticancer prodrug and conjugate design. Curr. Med. Chem. 2008, 15, 1802-1826.

140. Onkal, R; Djamgoz, M.B.A. Molecular pharmacology of voltage-gated sodium channel expression in metastatic disease: clinical potential of neonatal Nav 1.5 in breast cancer. Eur. J. Pharmacol. 2009, 625, 206-219.

(C) 2010 by the authors; licensee MDPI, Basel, Switzerland. This article is an open-access article distributed under the terms and conditions of the Creative Commons Attribution license (http://creativecommons.org/licenses/by/3.0/). 